EXPANDED CINEMA 



\title{
EXPANDED CINEMA
} Fiftieth Anniversary Edition

\author{
Gene Youngblood \\ Introduction by R. Buckminster Fuller
}




\section{MEANING SYSTEMS \\ Bruce Clarke and Henry Sussman, series editors}

Copyright () 2020 Fordham University Press

Previously published by E. P. Dutton \& Co., Inc., () 1970 by Gene Youngblood

Introduction to the Fiftieth Anniversary Edition @ 2020 Fordham University Press

Introduction and Poem "Inexorable Evolution and Human Ecology" copyright () 1970 by R. Buckminster Fuller

All rights reserved. No part of this publication may be reproduced, stored in a retrieval system, or transmitted in any form or by any means-electronic, mechanical, photocopy, recording, or any other-except for brief quotations in printed reviews, without the prior permission of the publisher.

Fordham University Press has no responsibility for the persistence or accuracy of URLs for external or third-party Internet websites referred to in this publication and does not guarantee that any content on such websites is, or will remain, accurate or appropriate.

Fordham University Press also publishes its books in a variety of electronic formats. Some content that appears in print may not be available in electronic books.

Visit us online at www.fordhampress.com.

Library of Congress Cataloging-in-Publication Data available online at https://catalog.loc.gov.

Printed in the United States of America

$222120 \quad 54321$

First edition 
To Jane 
